\title{
АНАЛІЗ ІСНУЮЧИХ МЕТОДІВ ЕКОНОМІЧНОЇ ОЦІНКИ ЕФЕКТИВНОСТІ ПРОМИСЛОВИХ ІННОВАЦІЙ
}

\section{А. В. Кравчук}

Національний технічний університет «Харківський політехнічний інститут» вул. Кирпичова, 2, м. Харків, 61002, Україна. E-mail: alina.kravchuk1601@gmail.com

Економічна оцінка ефективності інновацій є важливим етапом, за допомогою якого ще на ранніх стадіях інноваційних проектів можна відібрати найефективніші інновації та відхилити нераціональні пропозиції. Складність інноваційної діяльності полягає в тривалості життєвого циклу інноваційного товару, що потребує проведення економічної оцінки інновації на кожній його стадії. В роботі проведено дослідження та порівняльний аналіз традиційних та сучасних, статичних та динамічних методів економічної оцінки ефективності промислових інновацій. Визначено переваги та недоліки існуючих методик з урахуванням життєвого циклу інновації, що сприятиме розвитку та удосконаленню цих методів для прийняття раціональних управлінських рішень та ефективного використання ресурсів на підприємствах для підвищення ефективності їх інноваційної діяльності. В результаті дослідження запропоновано використання відповідних методів оцінки ефективності інновацій на різних стадіях життєвого циклу інновацій, що обумовлено їх особливостями, відмінністю критеріїв та показників ефективності.

Ключові слова: ефективність, аналіз методів, економічна оцінка, життєвий цикл інновації, промислові інновації.

\section{АНАЛИЗ СУЩЕСТВУЮЩИХ МЕТОДОВ ЭКОНОМИЧЕСКОЙ ОЦЕНКИ ЭФФЕКТИВНОСТИ ПРОМЫШЛЕННЫХ ИННОВАЦИЙ}

\section{А. В. Кравчук}

Национальный технический университет «Харьковский политехнический институт»

ул. Кирпичева, 2, м. Харьков, 61002, Украина. E-mail: alina.kravchuk1601@gmail.com

Экономическая оценка эффективности инноваций является важным этапом, с помощью которого еще на ранних стадиях инновационных проектов можно отобрать наиболее эффективные инновации и отклонить нерациональные предложения. Сложность инновационной деятельности заключается в продолжительности жизненного цикла инновационного товара, что делает необходимым проведение экономической оценки инновации на каждой его стадии. В работе проведено исследование и сравнительный анализ традиционных и современных, статических и динамических методов экономической оценки эффективности промышленных инноваций. Определены преимущества и недостатки существующих методик с учетом жизненного цикла инновации, что будет способствовать развитию и совершенствованию этих методов для принятия рациональных управленческих решений и эффективного использования ресурсов на предприятиях для повышения эффективности их инновационной деятельности. В результате исследования предложено использование соответствующих методов оценки эффективности инноваций на разных стадиях жизненного цикла инноваций, что обусловлено их особенностями, отличием критериев и показателей эффективности.

Ключевые слова: эффективность, анализ методов, экономическая оценка, жизненный цикл инновации, промышленные инновации.

АКТУАЛЬНІСТЬ РОБОТИ. У сучасних ринкових умовах успіх будь-якого підприємства визначається рівнем його інноваційної активності, тому значущість проведення ії оцінки є вкрай важливим та необхідним заходом, при цьому вагомим чинником $є$ вибір найбільш оптимального методу оцінки промислових інновацій. Від доцільності використання того чи іншого методу залежить коректність оцінки, яка служить основою для прийняття управлінських рішень, розробки подальших дій та стратегій для розвитку підприємства. Незважаючи на велику кількість існуючих теоретичних та практичних здобутків в методології оцінювання ефективності промислових інновацій, на сьогодні не вироблений єдиний універсальний метод, а кожен з безлічі методів має свої недоліки, що робить актуальним дослідження та аналіз існуючих методів економічної оцінки ефективності промислових інновацій.

Дослідженню методів економічної оцінки промислових інновацій приділяється велика увага фахівців-практиків та присвячується велика кількість робіт вітчизняних та зарубіжних економістів- науковців [1-27]. В результаті аналізу літератури було виявлено, що система оцінки промислових інновацій достатньо розроблена, проте іiі застосування на практиці є досить дискусійним. Глибоке вивчення даної проблеми в сучасній економічній літературі свідчить про те, що ряд питань залишаються недостатньо відкритими та дослідженими, що вимагає подальшого розвитку та уточнення.

Мета роботи - аналіз та дослідження існуючих методів економічної оцінки ефективності промислових інновацій, виділення їх переваг, недоліків та напрямів вдосконалення.

МАТЕРІАЛ І РЕЗУЛЬТАТИ ДОСЛІДЖЕНЬ. Економічна оцінка ефективності інноваційної діяльності включає в себе детальний розгляд запропонованих інновацій, їх аналіз і відбір, що дозволяе визначити привабливість промислових інновацій i виявити можливості та перспективи реалізації підприємством того чи іншого інноваційного проекту. Враховуючи високий рівень конкурентної боротьби, діяльність сучасного підприємства повинна мати систему, засновану на постійному проведенні оцін- 
ки та впровадженні заходів по підвищенню інноваційної активності. Велика кількість методів та показників, які застосовуються при економічній оцінки ефективності промислових інновацій позбавляють процедуру діагностики системності, а іноді й коректності, що перешкоджає виявленню проблемних питань та прийняттю адекватних управлінських рішень. На сьогодні кожне підприємство та кожен автор, опираючись на власні погляди та сферу діяльності, використовують різні методи оцінки, які не завжди в повній мірі характеризують реальний стан промислових інновацій або інноваційних проектів.

В сучасній літературі існує численна кількість методів економічної оцінки промислових інновацій, серед яких можна виділити найбільш поширені традиційні статичні та динамічні методи. Слід зазначити, що статичні методи оцінки ефективності інновацій $є$ простими методами, які використовуються, як правило, при експрес-аналізі інноваційних проектів 3 невеликою тривалістю. Серед статичних методів виділяють наступні показники:

1. Сумарний прибуток або чистий дохід від реалізації інноваційного проекту у вигляді різниці між сукупними результатами витратами на реалізацію проекту. Чим більше позитивна різниця показника, тим ефективніший проект.

2. Середньорічний прибуток, визначається усередненим значенням сумарного прибутку за період, що розглядається.

3. Рентабельність інвестицій (інвестиційного проекту), розраховується як відношення розміру прибутку в розрахунку до однієї гривні вкладених інвестицій.

4. Термін окупності інвестицій, період часу, який потрібен, щоб інвестиції забезпечили достатні надходження для відшкодування інвестиційних витрат [1]. Чим раніше настає термін окупності, тим більший прибуток та ефективніший інноваційний проект.

Великою перевагою статичних методів оцінки ефективності інноваційних проектів $є$ їх простота, швидкість та зручність в застосуванні, особливо слід зазначити можливість застосування статичних методів для попередніх оцінок на початкових етапах життєвого циклу промислових інновацій, в умовах відсутності достовірних даних про доходи і витрати, одержуваних від інвестиційного проекту. Основними недоліками цих методів $є$ приблизна оцінка варіантів інновацій, що розглядаються, під час розрахунку не враховується змінення вартості грошей у часі та дані методи не дозволяють встановлювати відмінності між проектами, що мають однаковий середньорічний обсяг прибутку, що може привести до недооцінки проекту.

Для виключення цих недоліків для оцінки ефективності інноваційних проектів застосовуються динамічні методи, в яких всі показники враховують фактор часу та дозволяють призвести техніку дисконтування, тобто приведення майбутніх грошових потоків до справжнього періоду.

Найбільш відомою динамічною методикою, яка використовується для оцінки ефективності інноваційної діяльності є методика обгрунтування ефективності інвестиційних проектів, розроблена Організацією Об'єднаних Націй з промислового розвитку (ЮНІДО). Відповідно до неї ефективність капітальних вкладень оцінюється за наступними показниками: чиста поточна вартість (NPV), яка використовує величину ставки дисконтування (R), індекс рентабельності інвестицій (PI), термін окупності інвестицій (DPP) і внутрішню норму прибутку (IRR) [2].

$$
N P V=\sum_{t=0}^{n} \frac{C F_{t}}{(1+R)^{t}},
$$

де $\mathrm{n}, \mathrm{t}$ - кількість часових періодів; $\mathrm{CF}_{\mathrm{t}}$ - грошовий потік (Cash Flow); R - вартість капіталу (ставка дисконтування, Rate).

Для розрахунку чистої поточної вартості з урахуванням вартісної оцінки супутніх соціальних i екологічних корисних результатів представляється наступна формула, яка для деяких авторів є більш зрозумілішою та зручнішою [3]:

$$
N P V=\sum_{t=0}^{n}\left(\Pi_{t}+A_{t}+E_{t}-H_{t}+\Pi_{t}\right) \times(1+R)^{-t}-K_{\Sigma},
$$

де $\Pi_{t}$ - прибуток від реалізації проекту в $t$-мy році; $A_{t}$ - амортизація в $t$-мy році; $E_{t}-$ вартісна оцінка корисних супутніх соціальних, екологічних і економічних результатів в $t$-мy році; $H_{t}$ - податок на прибуток в $t$-мy році; $J_{t}$ - ліквідаційне сальдо або виручка від продажу основних фондів, що вибувають в $t$-мy році, за вирахуванням витрат по їх реалізації; $K_{\Sigma}$ - сумарні капітальні вкладення на реалізацію проекту, приведені до початкового моменту часу; $R$-річний коефіцієнт дисконтування.

Критерієм ефективності інвестиційного проекту $\epsilon$ позитивне значення чистої поточної вартості (NPV), що вказує на прибутковість проекту та приріст ринкової вартості підприємства внаслідок реалізації інноваційного проекту. Якщо ж значення негативне, то впровадження проекту недоцільне. Недоліком даного показника є відсутність єдиного підходу $[1-6,11,12,18,19]$ щодо сутності його поняття, формули розрахунку та її складових.

Дисконтування чистої поточної вартості здійснюється з використанням ставки дисконтування (R).
Ставка дисконтування - це необхідна прибутковість інвестора на інвестиційні вкладення в інноваційний проект, що оцінюється, іншими словами, обгрунтування ставки дисконту пов'язано 3 оцінкою рівня ризику вкладень в проект [4], яка розраховується, як правило, за кумулятивним методом (CMM - Cumulative Capital Model) на основі експертної оцінки індивідуальних ризиків проекту за наступною формулою [2]: 


$$
R=i+s+\sum_{j=1}^{J} g_{i}
$$

де $\mathrm{i}$ - реальна безризикова ставка позичкового відсотку (без урахування інфляціi); s - інфляційні очікування; $\mathrm{j}=1 \ldots \mathrm{J}$ - множина чинників ризику, які враховуються в проекті; g - премія за окремий ризик.

Методи індексу рентабельності (PI), термін окупності інвестицій (PP) і внутрішня норму рентабельності або прибутку (IRR) засновані на розрахунку чистого дисконтованого грошового потоку. Індекс рентабельності або прибутковості (Profitability Index) - це відносний показник ефективності інноваційного проекту, який розраховується як відношення дисконтованих доходів за весь період реалізації проекту до дисконтованих інвестиційних витрат, значення індексу характеризує рівень прибутковості на одиницю вкладених ресурсів [4]:

$$
P I=\frac{\left(\sum_{t=0}^{n} C F_{i}(1+R)^{-t}\right)}{I C},
$$

де $\mathrm{CF}_{\mathrm{t}}$ - грошовий потік в кінці періоду t; IC - сума інвестицій в інноваційний проект.

Інноваційний проект вважається ефективним, якщо виконується наступна нерівність PI $\geq 1$. Даний показник особливо зручно використовувати для оцінки альтернативних інвестиційних проектів, через його відносність та відтворення ефективності одиниці інвестицій.

Один 3 найбільш поширених показників оцінки ефективності промислових інновацій є термін окупності інвестицій (DPP - Dynemic Payback Period), який повинен відповідати наступній нерівності:

$$
D P P=\sum_{t=0}^{n} \frac{C F_{t}}{(1+R)^{t}} \geq I C .
$$

В сучасних ринкових умовах інноваційна діяльність підприємств піддається різного роду ризиків, тому чим довший термін окупності інвестицій, тим більше цей ризик для інноваційного проекту. Важливо зазначити, що динамічний термін окупності завжди буде більше статичного, через врахування зміни вартості грошей у часі, тобто дисконтування [5].

Також достатньо популярним для оцінки промислових інновацій $є$ показник внутрішньої норми рентабельності або прибутку (Internal Rate of Return), яка представляє собою ставку дисконту, яка прирівнює суму приведених доходів від інноваційного проекту до величини інвестицій, іншими словами при якій чистий дисконтований дохід (NPV) дорівнює нулю. IRR визначає максимально прийнятну ставку дисконтування, при якій можна інвестувати кошти без будь-яких витрат для інвестора:

$$
\sum_{t=0}^{n} \frac{C F_{t}}{(1+I R R)^{t}}-I C=0
$$

або,

$$
I R R=\sqrt[n]{\frac{C F_{t}}{I C}}-1
$$

На наш погляд, показнику IRR притаманні наступні недоліки. Показник внутрішньої норми прибутковості не дає можливості визначити, скільки принесе грошей інвестиція в абсолютних значеннях та завищує ефект від інвестицій, що усувається при розрахунку показника модифікованої внутрішньої норми прибутковості (MIRR - Modified Internal Rate Of Return), який використовується при неординарності грошового потоку, тобто коли великі відтоки коштів виникають не тільки на початку, але і в середині, і в кінці терміну проекту. При цьому дотримання рівності [6] можливе при двох та більше значеннях IRR, для виключення таких ситуацій показник IRR модифікують та розглядають притоки i відтоки грошових коштів окремо [4].

Економічна оцінка промислових інновацій за допомогою всіх цих показників $є$ дуже важливим етапом, за допомогою якого ще на ранніх стадіях інноваційних проектів можна відібрати найефективніші інновації та відхилити нераціональні пропозиції.

Теоретико-методичні положення вітчизняних методів оцінки інноваційної діяльності почали формуватися ще за часів директивної економіки, які можна умовно розділити на два періоди їх розвитку: 1959-1969pp. розроблені методики були засновані на оцінці порівняльній ефективності та 1977-1988pp. методики, що враховують фактор часу [6]. Одними 3 найбільш значних були наступні методики: «Методика визначення економічної ефективності використання в народному господарстві нової техніки, винаходів та раціоналізаторських пропозицій» (1) розроблена в 1977році та «Методичні рекомендації з визначення економічної ефективності заходів, спрямованих на прискорення НТП» (2) 1988 року. Згідно Методики (1) річний економічний ефект від впровадження нової техніки, розраховувався як економія на витратах, з урахуванням річного обсягу виробництва:

$$
E=\left(3_{1}-3_{2}\right) \times A_{2},
$$

де $\mathrm{E}$ - річний економічний ефект; $3_{1}, 3_{2}$ - приведені витрати на одиницю продукції, яка вироблялась за допомогою змінюваної і нової техніки відповідно; $\mathrm{A}_{2}$ - річний обсяг виробництва продукції за допомогою нової техніки в натуральних одиницях.

В свою чергу приведені витрати розраховуються у вигляді суми собівартості і нормативного прибутку:

$$
3=C+E_{H} \times K,
$$

де C - собівартість одиниці продукції (роботи), грн.; $\mathrm{E}_{\mathrm{H}}$ - нормативний коефіцієнт ефективності капітальних вкладень для всіх галузей $(0,15)$; К - питомі капітальні вкладення до виробничих фондів, грн.

Недоліком Методики (1) є врахування чинника часу шляхом приведення до одного моменту часу (початку розрахункового року), яке виконується множенням (до початку) та діленням (після початку) витрат і результатів відповідного року на коефіцієнт 
приведення, який визначається за формулою:

$$
\alpha_{t}=(t+E)^{t}
$$

де $\alpha_{t}-$ коефіцієнт приведення альфа; Е - норматив приведення $(0,1) ; \mathrm{t}$ - число років, що відокремлюють витрати і результати даного року від початку розрахункового року.

На нашу думку, підходи до оцінки інновацій, закладені в аналізованій методиці можна використовувати і сьогодні. Однак ми вважаємо, що оцінювати інноваційні проекти по приведеним витратам не зовсім коректно, оскільки продукція, виготовлена за старою технологією може мати менші приведені витрати, але бути неконкурентоспроможною на ринку на відміну від інноваційної продукції з високими приведеними витратами.

На відміну від Методики (1), в якій економічний ефект розраховується як економія на витратах, Методика (2) передбачає розрахунок ефекту через різницю між результатами та витратами:

$$
E_{t}=P_{T}-3_{T}
$$

де $\mathrm{E}_{\mathrm{T}}$ - економічний ефект від заходу НТП за розрахунковий період; $\mathrm{P}_{\mathrm{T}}$ - вартісна оцінка результатів здійснення заходу НТП за розрахунковий період; $3_{\text {т }}$ - вартісна оцінка витрат на здійснення заходу НТП за розрахунковий період.

Розрахунок економічного ефекту проводиться 3 обов'язковим використанням приведення до єдиного моменту часу - розрахункового року t. Періодом, до якого приводяться витрати, як правило, виступає рік перед початком реалізації. Приведення різночасових витрат і результатів до розрахункового року здійснюється шляхом множення їхньої величини за кожен рік на коефіцієнт приведення d:

$$
d_{t}=\left(1+E_{H}\right)^{t p-t},
$$

де $\mathrm{d}_{\mathrm{t}}$ - коефіцієнт приведення різночасових витрат $\mathrm{i}$ результатів; $\mathrm{E}_{\mathrm{H}}$ - норматив приведення різночасових витрат і результатів $(0,1) ; \mathrm{t}_{\mathrm{p}}-$ розрахунковий рік; $\mathrm{t}$ рік, витрати і результати якого приводяться до розрахункового року.

Вартісна оцінка результатів здійснення проекту $\mathrm{P}_{\mathrm{t}}$ згідно Методики (2) визначається як сума основ- них $\mathrm{P}_{\text {ot }}$ i супутніх $\mathrm{P}_{\mathrm{ct}}$ результатів. Сума основних результатів для нових предметів праці знаходиться за наступною формулою:

$$
P_{o t}=\left(\frac{Q_{t} \times Ц_{t}}{y_{t}}\right) \times d,
$$

де $\mathrm{Q}_{\mathrm{t}}$ - обсяг використання нових предметів праці в $\mathrm{t}$ му році; Ц - ціна одиниці продукції (з урахуванням ефективності іiі застосування), що випускається 3 використанням нового предмету праці в $\mathrm{t}-м у$ році; $\mathrm{y}_{\mathrm{t}}$ - питома витрата предметів праці на одиницю продукції, вироблену з їхнім застосуванням у t-му році.

Сума основних результатів для засобів праці тривалого користування має наступний вигляд:

$$
P_{o t}=\bigsqcup_{t} \times A_{t} \times B_{t},
$$

де Ц - ціна одиниці продукції, виробленої за допомогою нових засобів праці в t-му році; $\mathrm{A}_{\mathrm{t}}$ - кількість застосовуваних засобів праці в цьому ж році; $\mathrm{B}_{\mathrm{t}}$ продуктивність застосовуваних одиниць праці в tму році.

Вартісна оцінка супутніх результатів включає додаткові економічні результати в різних сферах народного господарства, а також економічні оцінки соціальних і екологічних наслідків реалізації заходів науково-технічного прогресу, що визначаються за формулою:

$$
P_{c t}=\sum_{j=1}^{n} R_{j t} \times C_{j t},
$$

де $\mathrm{P}_{\mathrm{ct}}$ - вартісна оцінка соціальних і екологічних результатів здійснення проекту в t-му році; $\mathrm{R}_{\mathrm{jt}}$ величина окремого результату (у натуральних одиницях) з урахуванням масштабів його впровадження в t-му році; $\mathrm{C}_{\mathrm{jt}}$ - вартісна оцінка одиниці окремого результату в t-му році; $\mathrm{n}$ - кількість показників, що враховуються при визначенні впливу проекту на довкілля і соціальну сферу.

Окрім того дана методика передбачає, що витрати на реалізацію проекту за розрахунковий період включають витрати на виробництво продукції $\left(3_{п}\right)$ та іiї використання $\left(3_{\text {и }}\right)$ за цей період і розраховуються однаково:

$$
3_{\Pi / И}=\sum_{t=t H}^{t k} 3_{t} \times d_{t}=\sum_{t=t H}^{t k}\left(\Pi_{t} \times K_{t} \times \Pi_{t}\right) \times d_{t}
$$

де $3_{t}$ - величина витрат усіх ресурсів у t-му році (включаючи витрати на одержання супутніх результатів) при виробництві і використанні продукції відповідно; $И_{t}-$ поточні витрати при виробництві і використанні продукції в t-му році без обліку амортизаційних відрахувань на реновацію; $\mathrm{K}_{\mathrm{t}}$ - одноразові витрати (капітальні вкладення, інвестиції) при виробництві і використанні продукції в t-му році; $Л_{t}-$ залишкова вартість (ліквідаційне сальдо) основних засобів, що вибули в t-му році.

Перевагою Методики (2) є можливість врахування окрім основних результатів, ще й супутніх (екологічних, соціальних та інших), які для деяких промислових інноваційних проектів можуть бути не менш вагоміші за економічні. Також дана методика дозволяє врахувати динаміку доходів та розходів протягом всього життєвого циклу інноваційного проекту. Проте слід зазначити, що в розглянутих методиках розрахунки здійснюються на основі нормативних коефіцієнтів, які визначалися без економічного обгрунтування та не враховують чинник ризику, що безумовно не можна вважати позитивним при проведенні економічної оцінки промислових інновацій, і як слідство невідповідність умовам оцінки в ринковій економіці. 
В методології оцінки ефективності промислових інновацій доцільно використовувати наступні принципи: принцип від попередньої оцінки на етапі прийняття рішення до загальної оцінки на кінцевому етапі, принцип сполучення статичних та динамічних оцінок, принцип сполучення кількісних і якісних оцінок, принцип урахування часу, здійснення оцінки 3 урахуванням динамічності впродовж всього життєвого циклу інновації [6].

Також не можна не погодитися 3 думкою Берта Перріна [7], що методологічний підхід до оцінки інновацій повинен мати можливість отримувати непередбачувані наслідки та ризики, забезпечити розуміння складних процесів, а також допомогти визначити висновки та наслідки, як від успішних проектів, так і від невдалих, бути достатньо гнучким та прозорим.

Складність інноваційної діяльності полягає в тривалості життєвого циклу інноваційного товару, що потребує проведення економічної оцінки інновації на кожній його стадії. Класичний життєвий цикл інновації (ЖЦІ) складається 3 декількох стадій: зародження (I), зростання (II), зрілість (III) та спад (IV). На нашу ж думку, найбільш доцільно розглядати ЖЦІ у вигляді, представленому на рис. 1, який має п’ять стадій: дослідження і розробка (I), впровадження (II), зростання (III), зрілість (IV) та занепад (новий розвиток) $(\mathrm{V})$.

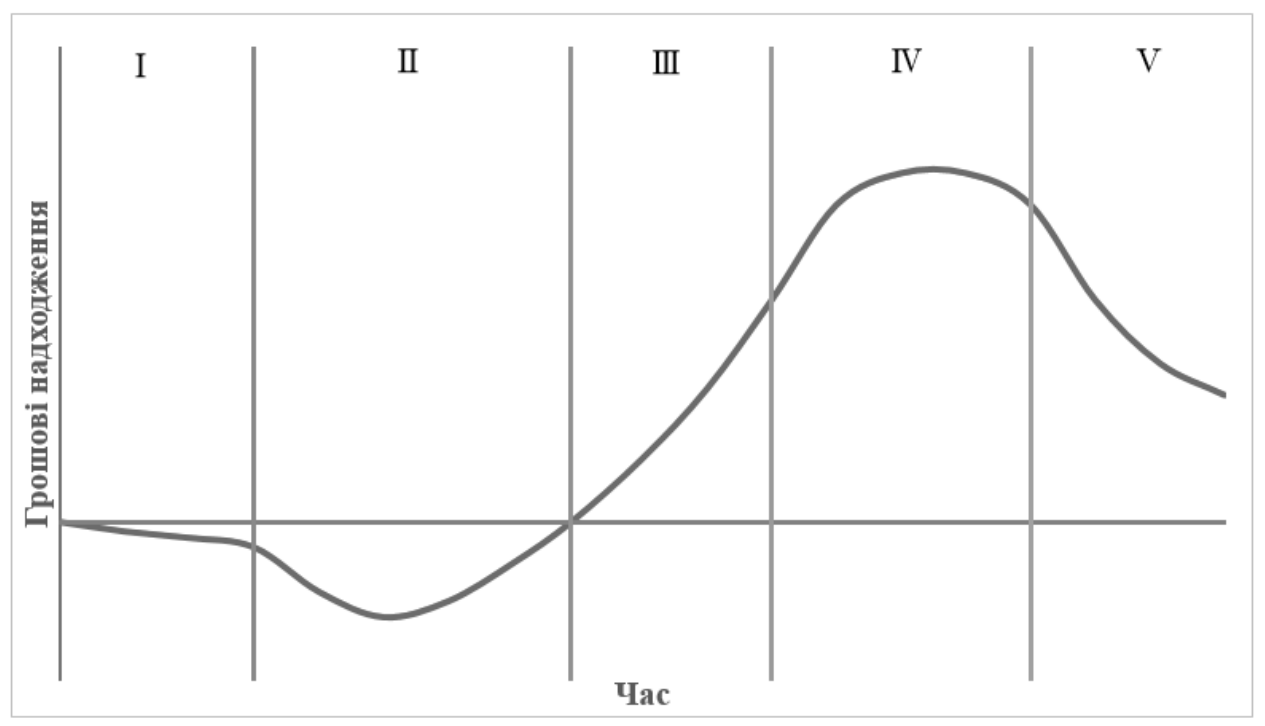

Рисунок 1 - Життєвий цикл інновації

Перша стадія - дослідження $і$ розробка інноваційного продукту. Слід зазначити, що ця стадія не завжди закінчується успішно, існує велика ймовірність невдач, ризиків і відстрочки одержання результатів. Результатом даної стадії $\epsilon$ готовий до впровадження продукт. На цьому етапі дуже важливо правильно оцінити доцільність даної інновації, оцінити всі ризики та можливості.

Стадія впровадження потребує значних витрат, це стадія збитків, відбувається технологічне освоєння масштабного виробництва інноваційної продукціï, виведення на ринок. При цьому обсяг виробництва повинен досягти рівня, який забезпечує беззбитковість роботи.

Третя стадія - стадія зростання. Результат - зростання виробництва та доходів, які можна реінвестувати на програми з розвитку інновації. Саме під час цієї стадії з'являються перші конкуренти.

Особливістю четвертої стадії (зрілість) є стабілізація обсягів виробництва, обсяг продажів, прибуток досягає максимальної точки, але також в стадії зрілості різко зростає конкуренція, оскільки відбувається дифузія (поширення) нововведення, інноваційний товар перестає бути єдино унікальним, відтак попит на нього скорочується, як наслідок починається п'ята стадія (занепаду), прибуток стрімко падає, після чого підприємства вимушені шукати конкурентні переваги шляхом здійснення іннова- ційної діяльності, тому стадію занепаду можна також називати стадією нового розвитку.

За останні роки вчені-економісти розробили безліч методів та моделей проведення економічної оцінки ефективності промислових інновацій. Проте в роботі проаналізовано та виявлено, що в сучасних методиках оцінки промислових інновацій недостатньо приділяється увага визначенню факторів ризику та характеристик промислових інновацій на ранніх стадіях оцінки інноваційних проектів, що може привести до впровадження економічно неефективних промислових інновацій [8]. Основу існуючих методичних розробок, які використовуються для економічної оцінки ефективності інновацій на початкових етапах життєвого циклу, становлять сучасні математичні методи прогнозування, такі як класична теорія ймовірностей і математична статистика, а також методи експертних оцінок, зокрема аксіологічна теорія ймовірностей, інтервальні методи і теорія нечітких множин. Дані методи дозволяють врахувати багатокритеріальність інновацій та високу невизначеність інноваційної діяльності. При оцінці промислових інновацій на стадіях наукового дослідження та розробки основною проблемою є недостатність кількісних показників та висока невизначеність інновацій, тому А.В. Маслобоєв та В.В. Максимова в своїй роботі пропонують застосування апарату теорії нечітких множин для оцінки 
ефективності інновацій на початкових етапах життєвого циклу товару. Такий підхід дозволяє генерувати безперервний спектр сценаріїв реалізації по кожному з прогнозованих параметрів інновації. Він дозволяє не тільки врахувати невизначеність, але i привести якісні (соціальна, екологічна, науково-

$$
\begin{gathered}
E_{\mathrm{int}}=\alpha_{1} \times E_{\text {ек }}+\alpha_{2} \times E_{\text {сои }}+\alpha_{3} \times E_{\text {нт }}+\alpha_{4} \times E_{\text {екол }}, \\
\alpha_{i}=\frac{2(n-i+1)}{n(n+1)},
\end{gathered}
$$

де $\mathrm{E}_{\text {ек}}, \mathrm{E}_{\text {соц }}, \mathrm{E}_{\text {нт }}, \mathrm{E}_{\text {екол }}$ - показники економічної, соціальної, науково-технічної та екологічної ефективності інновацій відповідно; $\alpha_{1}$ - ранги окремих показників ефективності інноваційного проекту (ступінь важливості окремого показника); n - кількість ранжируваних по ступені значимості окремих показників ефективності.

Головним недоліком методу теорії нечітких множин $є$ те, що основою даного методу є експертні оцінки, яким притаманна суб'єктивність та обмеженість суджень експертів.

У зарубіжній практиці популярним методом оцінки ефективності інновацій $є$ методика STAR (Strategic technology assessment review - огляд стратегічних технологічних оцінок), основою якої $\epsilon$ експертний підхід. Всього методика STAR включає 14 таблиць, в яких оцінюються 118 окремих факторів, здатних впливати на реалізацію та комерціалізацію інноваційного проекту. Головною перевагою даного методу $є$ комплексність технологічних та стратегічних аспектів [10].

Сучасні автори $[10,11]$ в своїх роботах розглядають метод комплексної оцінки. Розгорнутий аналіз на основі даної методики дає можливість оцінки різних видів інноваційних проектів та відсіяти завідомо неефективні проекти, однак даний метод не може передбачити всі сценарії можливого розвитку інновації. Також для оцінки інноваційного проекту застосовується метод експрес-аналізу, особливо зручний на етапі попередньої оцінки. Перевагами цього методу можна вважати швидкість розрахунків та невисоку трудомісткість, проте це може визивати за собою неточність розрахунків та їх вузькоспрямованість.

У своєму дослідженні Р.В. Бойко [12] пропонує метод оцінки, який передбачає розрахунок «граничного маржинального прибутку» (ГМП). Під ГМП розуміється зміна величини маржинального прибутку від збільшення обсягу виробництва і реалізації на одну одиницю. Для розрахунку граничного маржинального прибутку необхідно мати інформацію про сумарну виручку та сумарні величини змінних витрат на кожному етапі. Розраховується ГМП за формулою:

$$
\Gamma M \Pi_{i}=\frac{M \Pi_{i}-M \Pi_{i-1}}{n_{i}-n_{i-1}},
$$

де $\mathrm{MП}_{\mathrm{i}}$ - маржинальний прибуток на обсяг виробництва на i-му кроці; МП $_{\text {i- } 1-}$ маржинальний прибуток на обсяг виробництва на попередньому стосовно i-го кроку, тобто на i-1 кроці; $\mathrm{n}_{\mathrm{i}}$ - кількість продукції, виробленої на i-му кроці; $\mathrm{n}_{\mathrm{i}-1}-$ кількість продукції, виробленої на і-1 кроці.
Головною перевагою показника на думку P.В. Бойко $є$ те, що динаміка ГМП відтворює і динаміку прибутку, а саме там, де позитивна величина ГМП є найменшою при даному обсязі продаж, прибуток буде максимальним [12].

Динаміка поширення інновації за своєю суттю має дифузійну природу. Щодо поширення інновацій класичної стала точка зору Е. Роджерса, який визначив дифузію як процес, за допомогою якого інновація проходить по комунікаційним каналам в часі i просторі серед учасників соціально-економічної системи [13]. Обсяг дифузійних продуктів за час dt (дифузійні процеси) має наступний вираз, рішенням якого є логістична функція [14]:

$$
\begin{gathered}
d V=r V \times\left(1-\frac{v}{v_{m}}\right) \times d t, \\
V=\frac{v_{m}}{1+e^{(p-r t)}},
\end{gathered}
$$

де $\mathrm{V}$ - поточний обсяг використовуваних інновацій у середовищі; $\mathrm{V}_{\mathrm{m}}$ - рівень максимальних обсягів поширення інновації в середовищі; r - показник темпів дифузії інновації (коефіцієнт дифузії інновацій); p - показник затримки в часі початку дифузії інновації щодо початку системи відліку; е - основа натурального логарифму.

На основі даної моделі автори [14] пропонують використовувати модель дифузії інновації та заміщення її новою інновацією, більш досконалої порівняно $з$ попередньою, яка має наступний вигляд:

$$
V=\frac{v_{m 1}}{1+e^{(p 1-r 1 t)}}-k_{2} \frac{v_{m 2}}{1+e^{(p 2-r 2 t)}},
$$

де $\mathrm{V}_{\mathrm{m} 1}, \mathrm{~V}_{\mathrm{m} 2}$ - поточні обсяги поширення попередньої та подальшої інновацій.

Перевагою даної моделі є те, що вона описує не тільки фазу зростання в поширенні інновацій, а й фазу спаду або етап виходу з ринку.

Ще одну модель в якості методу оцінки дифузії інновацій розкриває в своїй роботі Р.І. Гільманова [15], а саме математичну модель дифузії інновацій Басса, яка описує, як інновації приймаються населенням та яка $є$ більш гнучкішою в порівнянні 3 логістичної моделлю: 


$$
n_{t}=\left(p+q \times \frac{N_{t}}{M}\right) \times\left(M-N_{t}\right),
$$

де $\mathrm{n}_{\mathrm{t}}$ - кількість, що прийняла інновацію в момент часу $\mathrm{t} ; \mathrm{N}_{\mathrm{t}}$ - сумарне число, що прийняли інновацію в момент часу $\mathrm{t} ; \mathrm{M}$ - потенціал ринку; $\mathrm{p}$ - коефіцієнт зовнішнього впливу; q - коефіцієнт внутрішнього впливу.
Особливості різних стадій життєвого циклу інновацій, відмінність їх критеріїв та показників ефективності обумовлюють використання й різних методів оцінки ефективності інновацій на цих стадіях, представлених в табл. 1 на основі дослідженої та аналізованої літератури.

Таблиця 1 - Оцінка ефективності інновацій на різних стадіях життєвого циклу

\begin{tabular}{|c|c|c|}
\hline $\begin{array}{c}\text { Стадія життєвого } \\
\text { циклу інновації }\end{array}$ & Критерії та показники ефективності інновацій & Методи оцінки \\
\hline $\begin{array}{l}\text { I Дослідження і } \\
\text { розробка }\end{array}$ & $\begin{array}{l}\text { новизна, практична користь та промислова } \\
\text { придатність новації, тривалість життєвого } \\
\text { циклу інновацій, коефіцієнт науково-технічної } \\
\text { результативності, техніко-економічна ефекти- } \\
\text { вність, чистий дисконтований дохід від } \\
\text { НДДКР }\end{array}$ & $\begin{array}{l}\text { Статичні методи, метод експертних } \\
\text { оцінок, теорія ймовірностей, апарат } \\
\text { теорії нечітких множин, методика } \\
\text { STAR, експрес-аналіз, метод NPV }\end{array}$ \\
\hline II Впровадження & $\begin{array}{l}\text { виробнича придатність, виробнича технологі- } \\
\text { чність, економічний ефект від впровадження } \\
\text { нововведення в порівнянні з аналогом, термін } \\
\text { окупності, рентабельність інвестицій, показ- } \\
\text { ник внутрішньої норми рентабельності, індекс } \\
\text { прибутковості, економія від зниження собіва- } \\
\text { ртості, від приведених витрат }\end{array}$ & $\begin{array}{l}\text { «Методика...» } 1977 \text { p. (1), «Методи- } \\
\text { чні рекомендації...» 1988p. (2), ста- } \\
\text { тичні методи, метод експертних } \\
\text { оцінок, методи NPV, PI, IRR, PP, } \\
\text { методика STAR, метод комплексної } \\
\text { оцінки, граничний маржинальний } \\
\text { прибуток }\end{array}$ \\
\hline $\begin{array}{l}\text { III Зростання } \\
\text { IV Зрілість } \\
\text { (збут) }\end{array}$ & $\begin{array}{l}\text { показник нових продажів, приріст обсягів } \\
\text { продажу, показник дифузії інновацій }\end{array}$ & $\begin{array}{l}\text { модель дифузії інновації, математи- } \\
\text { чна модель дифузї інновацій Басса, } \\
\text { граничний маржинальний прибуток }\end{array}$ \\
\hline $\begin{array}{l}\mathrm{V} \text { Занепад (новий } \\
\text { розвиток) }\end{array}$ & $\begin{array}{l}\text { показник дифузії інновації та заміщення їі } \\
\text { новою інновацією, (в випадку стадії «новий } \\
\text { розвиток» критерії та показники відповідають } \\
\text { І стадії ЖЦ) }\end{array}$ & $\begin{array}{l}\text { модель дифузії інновації та замі- } \\
\text { щення іії новою інновацією, гранич- } \\
\text { ний маржинальний прибуток, (в } \\
\text { випадку стадії «новий розвиток» } \\
\text { методи оцінки відповідають І стадії } \\
\text { ЖЦ) }\end{array}$ \\
\hline
\end{tabular}

Таким чином, кожна стадія життєвого циклу інновації має свої особливості та виконує конкретну роль в інноваційному процесі, тому виявлення всіх можливих ефектів та чинників є важливою умовою при проведенні економічної оцінки ефективності промислових інновацій. Важливо зазначити, що при виборі того чи іншого методу оцінки необхідно опиратися на різні аспекти, такі як розмір та галузь підприємства, його фінансові потоки, особливості інноваційних проектів та їх стадії життєвого циклу.

ВИСНОВКИ. Розвиток інноваційної діяльності промислових підприємств є одним з основних шляхів підвищення конкурентоспроможності вітчизняної продукції, відіграє ключову роль в економічному благополуччі країни та визначає їі місце на світовому ринку. Виходячи з цього, задача оцінки ефективності промислових інновацій та якісний відбір інноваційних проектів мають високе практичне значення на національному рівні. Враховуючи те, що серед розглянутих методів не існує універсального та уніфікованого, а кожен з них має свої недоліки, то можна зробити висновок, що перед економістами-науковцями стоїть завдання по розробці більш довершеного метода економічної оцінки промислових інновацій з урахуванням стадій життєвого циклу. Дане питання є проблемою як теоретичної сфери, так і практичної, оскільки недостатня увага до даної проблеми може призвести до фінансових збитків через недостовірні дані та прийняті на їх основі управлінських рішень. А розуміння недоліків та переваг існуючих методів оцінки ефективності промислових інновацій повинно сприяти розвитку та удосконаленню цих методів, що допоможе менеджерам в прийнятті раціональних рішень та ефективному використанні ресурсів на вітчизняних підприємствах для підвищення ефективності їх інноваційної діяльності.

\section{ЛІТЕРАТУРА}

1. Елохова И. В., Малинина С. Е. Современные проблемы оценки экономической эффективности инновационных проектов. Вестник Пермского университета. 2014. № 3. С. 74-81.

2. Гонин В. Н., Кошурников А. Н., Ханчук Н. Н. Методические подходы оценки эффективности инновационной деятельности в экономических системах. Вестник Бурятского государственного университета. 2014. № 2. С. 6-12.

3. Перерва П. Г., Долина І. В., Кобелєв В. М. Дослідження та аналіз проблемно-орієнтованих 
оцінок ефективності технологічних інновацій. Bicник Національного технічного університету «ХПI». Технічний прогрес $i$ ефективність виробництва. 2006. № 41 (1). С.62-73.

4. Лаврухина Н. В. Сравнительный анализ методов оценки экономической эффективности инвестиций. Теория и практика общественного развития. 2014. № 16. С. 82-86.

5. Кравчук А. В., Перерва П. Г. Аналіз традиційних методів економічної оцінки промислових інновацій. Актуальні питання організації та управління діяльністю підприємств у сучасних умовах господарювання : електрон. вид. : зб. тез доп. 8-і наук.-практ. конф., 29 листопада 2018 р., м. Харків / Нац. акад. Нац. гвардії України. Електрон. текстові дані. Харків, 2018. С.120-121. URL: http://nangu.edu.ua/wp-

content/uploads/2019/01/\%D0\%97\%D0\%B1\%D1\%96 $\% \mathrm{D} 1 \% 80 \% \mathrm{D} 0 \% \mathrm{BD} \% \mathrm{D} 0 \% \mathrm{~B} 8 \% \mathrm{D} 0 \% \mathrm{BA}-$

$\% \mathrm{D} 1 \% 82 \% \mathrm{D} 0 \% \mathrm{~B} 5 \% \mathrm{D} 0 \% \mathrm{~B} 7+29.11 .18 \% \mathrm{D} 0 \% \mathrm{BA} \% \mathrm{D}$ $1 \% 96 \% \mathrm{D} 0 \% \mathrm{BD} \% \mathrm{D} 1 \% 86 \% \mathrm{D} 0 \% \mathrm{~B} 5 \% \mathrm{D} 0 \% \mathrm{~B} 2 \% \mathrm{D} 0 \% \mathrm{~B} 8$ \%D0\%B9+.pdf (дата звернення: 08.02.2019 р.).

6. Чорна М. В., Глухова С. В. Оцінка ефективності інноваційної діяльності підприємств: монографія. Харків : ХДУХТ, 2012. 210с.

7. Perrin B. How to - and How Not to - Evaluate Innovation. Evaluation. 2002. Vol.8(1). pp. 13-28.

8. Кравчук А. В., Перерва П. Г. Механізм передпланової оцінки промислових інновацій. XII Міжнародна науково-практична конференція магістрантів ma аспірантів :матеріали конф., 17-20 квітня 2018 р. : у 3 ч. Ч. 1 / ред. С. І. Сокол. Харків : НТУ "ХПІ", 2018. С. 190.

9. Маслобоев А. В., Максимова В. В. Метод и технология комплексной оценки эффективности инноваций на начальных этапах жизненного цикла на основе математического аппарата теории нечетких множеств. Труды Кольского научного иентра РАН. 2010. № 3. С. 50-66.

10. Куликов Д. Л., Кучеров А. А. Становление и развитие методов оценки эффективности инновационных проектов. Современные проблемы науки $u$ образования. 2015. №1 [Электронный ресурс] URL:: https://www.science-

education.ru/ru/article/view?id=19451 (дата звернення: 24.02.2019)

11. Шаблиста Л. М. Фінансова стійкість підприємства: сутність і методи оцінки. Економіка $i$ прогнозування. 2006. № 2. С. 46-57.

12. Бойко Р. В. Економічна оцінка інноваційного продукту. Вісник Технологічного університету Поділля. 2000. № 4. Ч. II. С. 116-122.

13. Баканова С. А. Механизмы диффузии инноваций: особенности и методы моделирования. Научно-технические ведомости СПбГПУ. Серия «Экономические науки». 2013. № 6-1. С. 144-149.

14. Минаков В. Ф., Минакова Т. Е., Барабанова М. И. Экономико-математическая модель этапа коммерциализации жизненного цикла инноваций. Научно-технические ведомости СПбГПУ. Серия
«Экономические науки». 2012. № 2-2. С. 180-184.

15. Гильманова Р. И. Методы оценки экономической эффективности инноваций с учетом их жизненного цикла. Электронный научный журнал «Управление экономическими системами». 2011. № 28. C. 181-192.

16. Шевчук А. М. Основні методи оцінки ефективності інвестиційних проектів на підприємствах у сучасних умовах господарювання. Стратегія $i$ механізми регулювання промислового розвитку: Зб. наук. пр. Донецьк: ІЕП НАН. 2009. С. 354-365.

17. Касаткина Е. В. Оценка эффективности инвестиционных проектов: методологические проблемы и направления их решения. Известия Российского государственного педагогического университета им. А.И. Гериена. 2010. № 126. С. 42-51.

18. Причепа I. В. Аналіз методичних підходів до оцінки інноваційного потенціалу підприємства. Економіка і регіон. 2010. № 1. С. 84-89.

19. Тарасенко I. А., Королько О. Н., Белявська К. С. Оцінка інноваційної активності підприємства в системі стратегічного управління. Актуальні проблеми економіки. 2009. № 9 (99). С. 133-141.

20. Овєчкіна О. А., Іванова К. В. Огляд методів оцінки рівня інноваційного потенціалу економічних суб'єктів. Економічний вісник Донбасу. 2007. № 4(10). С. 130-140.

21. Демичев Г. Г., Тебекин А. В. Совершенствование процессов управления параметрами жизненного цикла инноваций на стадии испытаний, сертификации и стандартизации новых процессов и продуктов. Транспортное дело России. 2010. № 12. C. $91-94$.

22. Самолдин А. Н. Жизненный цикл инноваций. Вестник Университета «Экономика: проблемы, решения и перспективы». 2015. № 2. С. 127-132.

23. Горохова А. Е. Оценка инноваций: экономическое содержание и обеспечение. Известия МГТУ «МАМИ». 2013. № 1 (15). С. 200-206.

24. Martinsuo M., Poskela J. Use of Evaluation Criteria and Innovation Performance in the Front End of Innovation*. Journal of Product Innovation Management. 2011. Vol. 28(6). P. 896-914.

25. Cooper R. G. Stage-gate systems: A new tool for managing new products. Business Horizons. 1990. Vol. 33(3). P. 44-54.

26. Демченко Г. В. Розробка концептуальної моделі розвитку організаційного забезпечення активізації інноваційної діяльності промислового підприємтсва. Вісник Кременчуизкого національного університету імені Михайла Остроградського. 2017. Вип. 4/2017 (105). С. 103-109.

27. Оболенцева Л. В. Економічна діяльність регіональних промислових комплексів україни: наукові підходи щодо оцінювання. Вісник Кременчуизького національного університету імені Михайла Остроградського. 2018. Вип. 6/2018 (113). C. $130-135$. 


\section{ANALYSIS OF THE EXISTING METHODS OF AN ECONOMIC EVALUATION OF THE EFFICIENCY OF INDUSTRIAL INNOVATIONS}

\section{A. Kravchuk}

National Technical University «Kharkiv Polytechnic Institute»

vul. Kyrpychova, 2, Kharkiv, 61002, Ukraine. E-mail: alina.kravchuk1601@gmail.com

Purpose. Analysis and research of existing methods of economic evaluation of efficiency of industrial innovations, their advantages, disadvantages and directions of their improvement is the purpose of the article. Methodology. Research and comparative analysis of traditional and modern, static and dynamic methods of the economic evaluation of the efficiency of the industrial innovations were performed. The advantages and disadvantages of the existing methods with an innovation life cycle were considered. Findings. The use of appropriate methods for evaluating the efficiency of the innovations at different stages of the innovation life cycle in terms of their features, the difference in criteria and performance indicators was proposed as a result of the study. Originality. The complexity of innovation activity consists in a duration of the innovative product life cycle, which requires the economic evaluation of the innovations at each stage. In spite of a large number of methods of the economic evaluation of innovations, there is no universal and unified method among the considered ones, and each of them has its own disadvantages. Nowadays each enterprise and each author use different valuation methods based on their own views and field of activity that does not always fully describe the actual state of industrial innovations or innovation projects. Therefore, today this issue remains insufficiently explored, open and controversial, requiring further study and improvement. Practical value. Analysis and research of existing methods of economic evaluation of industrial innovations efficiency, understanding their advantages and disadvantages will contribute to a development and an improvement of these methods for making rational management decisions and an efficient use of resources at enterprises in order to increase the efficiency of their innovation activities. Every stage of the innovation life cycle has its own peculiarities and fulfills a specific role for the innovation process, so an identification of all possible effects and factors is an essential condition for conducting an economic evaluation of the efficiency of industrial innovations. Conclusions. The economic evaluation of the efficiency of the innovations is important stage which allows select the most effective innovations and reject irrational proposals in the early stages of innovative projects. References 27 , tables 1 , figures 1 .

Key words: efficiency, analysis of methods, economic evaluation, innovation life cycle, industrial innovations.

\section{REFERENCES}

1. Elokhova, I. V., Malinina, S. E. (2014), "Modern problems of assessing the economic efficiency of innovative projects", Vestnik Permskogo universiteta, no. 3, pp. 74-81.

2. Gonin, V. N., Koshurnikov, A. N., Khanchuk, N. N. (2014), "Methodical approaches to assess the effectiveness of innovation in economic systems", Vestnik Buryatskogo gosudarstvennogo universiteta, no. 2, pp. 6-12.

3. Pererva, P. H., Dolyna, I. V., Kobelyev, V. M. (2006), "Research and analysis of problem-oriented estimations of efficiency of technological innovations", Visnyk Natsional'noho tekhnichnoho universytetu «KHPI». Tekhnichnyy prohres $i$ efektyvnist vyrobnytstva, no. 41(1), pp. 62-73.

4. Lavrukhina, N. V. (2014), "Comparative analysis of methods for assessing the economic efficiency of investments", Teoriya $i$ praktika obshchestvennogo razvitiya, no. 16, pp. 82-86.

5. Kravchuk, A. V., Pererva, P. H. (2018), “Analysis of traditional methods of economic evaluation of industrial innovations", Aktual'ni pytannya orhanizatsiyi ta upravlinnya diyal'nistyu pidpryyemstv u suchasnykh umovakh hospodaryuvannya : elektron. vyd. : zb. tez dop. 8-yi nauk.-prakt. konferentsii [Topical issues of organization and management of the enterprises in the modern conditions of management, el. edition: Proceedings of the 8th Scientific and Practical Conference], 29 lystopada 2018 r., m. Kharkiv, Nats. akad. Nats. hvardyiyi Ukrayiny. Elektron. tekstovi dani. Kharkiv,2018, pp. 120-121. available at: http://nangu.edu.ua/wpcontent/uploads/2019/01/\%D0\%97\%D0\%B1\%D1\%96 $\% \mathrm{D} 1 \% 80 \% \mathrm{D} 0 \% \mathrm{BD} \% \mathrm{D} 0 \% \mathrm{~B} 8 \% \mathrm{D} 0 \% \mathrm{BA}-$
$\% \mathrm{D} 1 \% 82 \% \mathrm{D} 0 \% \mathrm{~B} 5 \% \mathrm{D} 0 \% \mathrm{~B} 7+29.11 .18 \% \mathrm{D} 0 \% \mathrm{BA} \% \mathrm{D}$ $1 \% 96 \% \mathrm{D} 0 \% \mathrm{BD} \% \mathrm{D} 1 \% 86 \% \mathrm{D} 0 \% \mathrm{~B} 5 \% \mathrm{D} 0 \% \mathrm{~B} 2 \% \mathrm{D} 0 \% \mathrm{~B} 8$ $\% \mathrm{D} 0 \% \mathrm{~B} 9+. \mathrm{pdf}$

6. Chorna, M. V., Hlukhova, S. V. (2012), "Evaluating the effectiveness of enterprise innovation activity: monograph", KHDUKHT, Kharkiv, 210 p.

7. Perrin, B. (2002), "How to - and How Not to Evaluate Innovation", Evaluation, vol. 8(1), pp. 13-28.

8. Kravchuk, A. V., Pererva, P. H. (2018), "Preplanned evaluation mechanism of industrial innovation", XII Mizhnarodna naukovo-praktychna konferentsiya mahistrantiv ta aspirantiv :materialy konferentsii [XII International Scientific and Practical Conference of Graduate Students and Postgraduate Students: Proceedings of Conference Title],17-20 kvitnya 2018, Kharkiv : NTU "KHPI", 2018. pp. 190.

9. Masloboyev, A. V., Maksimova, V. V. (2010), "The method and technology of a comprehensive assessment of the effectiveness of innovation in the initial stages of the life cycle based on the mathematical apparatus of the theory of fuzzy sets", Trudy Kol'skogo nauchnogo tsentra RAN, no. 3. pp. 50-66.

10. Kulikov, D. L., Kucherov, A. A. (2015), "Formation and development of methods for evaluating the effectiveness of innovative projects", Sovremennyye problemy nauki $i$ obrazovaniya, available at: https://www.science-

education.ru/ru/article/view?id=19451

11. Shablysta, L. M. (2006), "Financial sustainability of the enterprise: the essence and methods of evaluation", Ekonomika i prohnozuvannya, no. 2, pp. 46-57.

12. Boyko, R. V. (2000), "Economic appraisal of an innovative product", Visnyk Tekhnolohichnoho universytetu Podillya, no. 4, Is. 2, pp. 116-122. 
13. Bakanova, S. A. (2013),"Innovation diffusion mechanisms: features and modeling methods", Nauchno-tekhnicheskiye vedomosti SPbGPU. Seriya «Ekonomicheskiye nauki», no. 6-1, pp. 144-149.

14. Minakov, V. F., Minakova, T. E., Barabanova, M. I. (2012), "Economic-mathematical model of the stage of commercialization of the life cycle of innovation", Nauchno-tekhnicheskiye vedomosti SPbGPU. Seriya "Ekonomicheskiye nauki», no. 2-2, pp. 180-184.

15. Gilmanova, R. I. (2011), "Methods for assessing the economic efficiency of innovation, taking into account their life cycle", Elektronnyy nauchnyy zhurnal "Upravleniye ekonomicheskimi sistemami», no. 28, pp. 181-192.

16. Shevchuk, A. M. (2009), "The main methods of assessing the effectiveness of investment projects in enterprises in modern economic conditions", Stratehiya $i$ mekhanizmy rehulyuvannya promyslovoho rozvytku: Zb. nauk. pr. Donets'k: IEP NAN, pp. 354-365.

17. Kasatkina, E. V. (2010), "Evaluation of the effectiveness of investment projects: methodological problems and their solutions", Izvestiya Rossiyskogo gosudarstvennogo pedagogicheskogo universiteta im. A.I. Gertsena, no. 126, pp. 42-51.

18. Prychepa, I. V. (2010), "Analysis of methodical approaches to the assessment of the innovative potential of the enterprise", Ekonomika i rehion, no. 1, pp. 84-89.

19. Tarasenko, I. A., Korolko, O. N., Belyavskaya, K. S. (2009), "Estimation of innovation activity of the enterprise in the system of strategic management", Aktual'ni problemy ekonomiky, no. 9(99), pp. 133-141.
20. Ovyechkina, O. A., Ivanova, K. V. (2007), “An overview of methods for assessing the level of innovative potential of economic entities", Ekonomichnyy visnyk Donbasu, no. 4(10), pp. 130-140.

21. Demichev, G. G., Tebekin, A. V. (2010), "Improving the processes of managing the parameters of the life cycle of innovation at the stage of testing, certification and standardization of new processes and products", Transportnoye delo Rossii, no. 12, pp. 91-94.

22. Samoldin, A. N. (2015), "The life cycle of innovation”, Vestnik Universiteta «Ekonomika: problemy, resheniya i perspektivy», no. 2, pp. 127-132.

23. Gorokhova, A. E. (2013), "Evaluation of innovation: economic content and provision", Izvestiya $M G T U$ «MAMI», no. 1(15), pp. 200-206.

24. Martinsuo, M., Poskela, J. (2011), "Use of Evaluation Criteria and Innovation Performance in the Front End of Innovation", Journal of Product Innovation Management, vol. 28(6). pp. 896-914.

25. Cooper, R. G. (1990), "Stage-gate systems: A new tool for managing new products", Business Horizons, vol. 33(3), pp. 44-54.

26. Demchenko, H. V. (2017), "Development of a conceptual model for the development of organizational support for activating innovation activity of industrial enterprises", Transactions of Kremenchuk Mykhailo Ostrohradskyi National University, no. 4/2017 (105), pp. 103-109.

27. Obolentseva, L. V. (2018), "Economic activity of regional industrial complexes in Ukraine: scientific approaches to evaluation", Transactions of Kremenchuk Mykhailo Ostrohradskyi National University, no. 6/2018 (113), pp. 130-135.

Стаття надійшла 04.03.2019. 